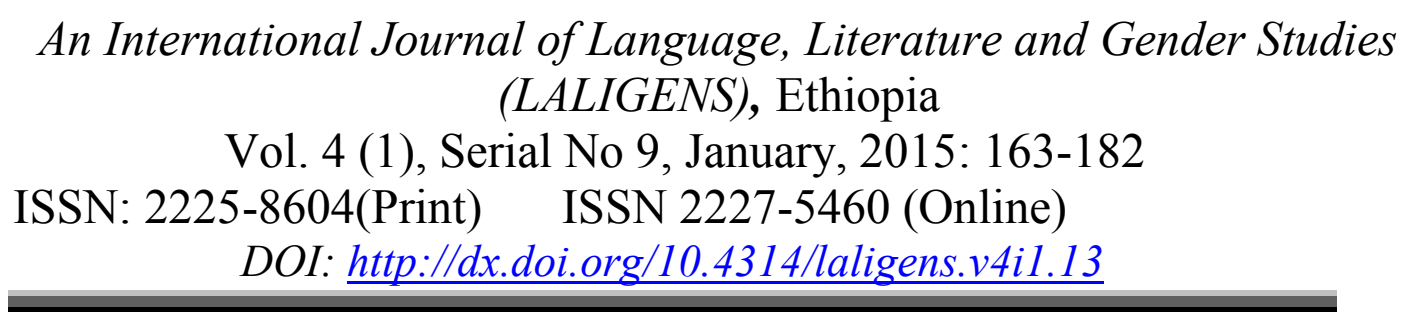

\title{
The Views of Women of Press Coverage of Rape Cases in Nigeria: A Misrepresentation or an Under-representation?
}

\author{
Nwammuo, Angela Nkiru, Ph.D. \\ Department of Mass Communication \\ Anambra State University \\ Igbariam Campus \\ Phone No: +23480369099 \\ E-mail: angelanwammuo@yahoo.com
}

\begin{abstract}
The degree of prominence given to events, issues or phenomena by the press goes a long way in determining people's knowledge, exposure, views, opinions and/or suggestions about such events, issues and phenomena. Thus, the degree of prominence given to rape cases by the press in Nigeria determines what Nigerians feel and know about rape and its attendant consequences. This is the bedrock of this study. It is aimed at ascertaining how Nigerian elite women view the coverage of rape cases by Nigerian press. It is a qualitative study in which focus Group Discussion method (involving ten women selected from five state universities in the South Eastern) was used in achieving the aim of the study. The findings show that respondents, view press coverage of rape cases as "under-representation" and not "Mis-representation". This is based on the cited newspapers which contain few rape cases which were mostly buried in inside pages. Based on this finding, the study recommends that journalists in Nigeria be more sensitive to the plight of rape victims by giving rape cases the prominence they deserve. This no doubt, will serve as deterrant to others who are likely to engage in this inhuman and devilish act.
\end{abstract}


Key words: Misrepresentation, under-representation, Rape, Press Coverage, Women's Views.

\section{Introduction}

Zairnab has become the latest victim of the rising cases of rape and violent crimes in the state. Indeed, these crimes are now occurring with frightening dimension in the North-East, no fewer than 95 child rape cases have been reported in five northern states with Gombe having 50 cases and Bauchi recording 11 cases. (Saturday Sun, March 152014 Reporting Child Protection Network (CPN) findings).

The above report by Saturday Sun of March 2014 is one of such worrisome cases of rape reported by the press. Oduah $(2014$, p. 26$)$ stressed that "the rate at which rapes occur in our society today is becoming alarming and outrageous". Musbau (2013, p. 53) reports that " 687 cases of rape were recorded" in 2012, which is an average of two cases per day, 100 cases of rape in Kano writes in 2013 out of which 40 offenders were convicted". In Anambra State, Guardian Newspaper of Friday 7, 2014 reports that there were with 115 rape incidents and complaints only 12 cases taken up by the police.

These were not the only rape cases reported in 2014. On January 10, 2014, a similar incident was reported by Daily Sun Newspaper. In this case, a seventeen year-old girl was gang raped by three men on her way back from school. On June $6^{\text {th }} 2013$, Guardian, Newspaper had it that Masonter Iyanga of Akwabo street raped a young girl. Vanguard Newspapers of $25^{\text {th }}$ October 2013 reported that a 50 years-old pastor of Choice Bible church allegedly raped three girls aged nine, seven and eight years. Also, Daily sun of October $31^{\text {st }} 2013$ had it that a virgin school girl at Ikorodu Lagos state was gang raped by these men to coma. As if all these cases were not enough, Daily Sun of $19^{\text {th }}$ December 2013 reported that a seven-year-old girl was gang raped by three men.

The above instances are ugly scenario that floods the Nigerian press on alarming rate. This is despite the provision made in section 357 of the Criminal Code Act CAP 77, Laws of the Federation which states that:

Any person who has lawful canal knowledge of a women or girl without her consent, if the consent is obtained by force or by means of threat by force or by means of threat or intimidation of any find or by fear of harm or by means of false and fraudulent representation as to the nature of the act, or, in the case of a married women, by impersonating her husband, is guilty of an offence which is called rape. 
Similarly, the child's Right Act of 2003 by virtue of section 31(1) (2) (3) of the Act maintains that:

No person shall have sexual intercourse with a child. A person who contravenes the provisions of sub-section (1) of this section commits an offence of rape and is liable on conviction to life imprisonment. It is immaterial that the offender believed the person to be of or above the age of eighteen or (that) the sexual intercourse was with the consent of the child.

The term "rape" is therefore the most serious kind of sexual assault and is punishable with imprisonment for life, (Okonkwo \& Naish, 2013).

It is also one of those actions that fall under violence against women (Nwammuo, 2013). One therefore is bound to ask: if rape is punishable with imprisonment for life as stipulated in various provisions of the laws of the Federation, how many persons have been imprisoned? And do the press give a follow up of how rape cases are tried in various courts? These mind bothering questions necessitated this research.

\section{Theoretical Framework}

This research work is based on Agenda setting theory of the press. This theory which was propounded by Maxwell McCombs and Donald show in 1972 is simply maintaining that the media determine what the people think about by frequently emphasizing on an issue and by giving it prominence, (Baran and Davis, 2003). Agenda is therefore an issue or subject of discussion which may be topical enough to elicit a positive or negative response from members of the public, (Asemah, 2011). This theory is therefore considered apt for this study because the prominence attached to rape cases by the press would determine to a great extent how Nigerians would see or be knowledgeable about rape cases and its attendant consequences. For instance, constant placement of rape cases, offenders and punishment meted out to them, in front pages and in editorials, will no doubt increase peoples knowledge of the crime.

In examining how the press set agenda on rape cases and how the press treats rape victims, the following newspapers were used in the course of study as reference materials that guided respondent's discussion:

1. Saturday Sun of March 15, 2014

2. Sunday Sun of August 31, 2014

3. Sunday Sun of January 19, 2014

4. Daily Sun of October 31, 2013

5. Daily Sun of December 19, 2013

6. Guardian of June 6, 2013

7. Guardian of November 3, 2013 


\section{8. $\quad$ Vanguard of October 25, 2013}

\section{See Appendix i - viii for the papers}

\section{Review of Related Literature}

This study reviewed three works done by scholars in the field of communication and gender. The first is a research work carried out by Oduah (2014) titled "Exploring Media Framing and Representation of Rape cases in Nigeria". The researcher content analyzed the Guardian, Vanguard and Daily Sun newspapers to ascertain the framing and representation of rape cases in Nigeria. The findings revealed that Daily sun newspaper report rape cases more than other newspapers in Nigeria.

The study also discovered that even when rape cases are reported, they were buried in inside pages of the newspapers thereby giving them little or no prominence. Finally, the study recorded that dominant frames of rape cases include innocence, neutral, intimidation and avoidance. Nwankwo, (2011) carried out a study to find out how Nigerian journalists cover crimes using content analysis as a research design. This study recorded that armed robbery is given high coverage while rape, house breaking and other related crimes are given low coverage by publishing them in inside pages Eboh, (2011); content analyzed Nigerian newspapers to findout how rape cases were reported. The study found that although Nigerian press reported some rape cases, readers were not given a follow-up on how those cases were tried. It also reported that out of 720 rape cases recorded in Anambra State in 2010, only 12 of the cases were reported to the police while none of the cases had been successfully prosecuted by the court.

It could therefore be deduced from these reviewed works that there has been how coverage of rape cases in Nigeria. Rape cases were also not given enough prominence as they were buried in inside pages of the cited newspapers.

All these reviewed works are similar to the present study but differ greatly in terms of methodology adopted. This present study used Focus Group Discussion method while using selected Nigerian Newspapers as reference materials. None of the works tried to findout how women themselves fell about press coverage of rape cases.

Thus, this presents study was carriedout in order to ascertain how women view coverage of rape cases since they are the victims of most crimes especially rape. Previous scholars did not ascertain human angles to their research endeavours. This is the gap which this study hopes to fill.

\section{Methodology}

This study adopted qualitative research approach in which Focus Group Discussion (FGD) was used in eliciting reliable responses from the respondents. This study purposively selected two women each from each of the state universities in the South 
East namely: Anambra, Abia, Enugu, Ebonyi and Imo States. These women, selected from the Department of Mass Communication in each institution, were lecturers who teach gender courses in their various institutions. This is because, this study falls under communication and gender category and these women were considered knowledgeable on the subjects of the study which were gender and media studies.

Explanation Building Techniques was used in the analyses and presentation of the outcome of the Focus Group Discussion. The FGD session lasted for five hours in which the discussants analyzed the contents of the cited newspapers which was given to them. Based on this, discussion was critically made on the subject of this study.

It could be pointed at this point that this study takes "misrepresentation" to mean presentation of false facts while "under-representation" refers to the presentation of lower number of rape cases when compared to presentation of other crimes.

\section{Findings/Discussion of the Focus Group Session}

The discussants fully and actively participated in the FGD session. They uniformly agreed to be knowledgeable on the subject of this study which is rape and its coverage by Nigerian press.

All the Discussants agreed that in comparism with other crimes such as corruption, kidnapping, armed robbery, and fraud, rape cases were given low coverage and prominence by Nigerian newspapers. Dr. Cynthia from ABSU was more outspoken on this when she said that:

Even a blind man or woman will tell you that journalists whether in print or electronic shy away from reporting rape cases. I don't think they consider it a serious crime that deserves their time and attention. And this may be the reason why rape victims do not even report to the police or press because they may not be helped at all. Some journalists will even tell you that we are not in Americans that this is Africa where such issues do not make news. It is indeed a pity!

This finding is in conformity with Oduah (2014) that found through content analysis that rape cases receive low reportage when compared with other crimes. In the analyzed newspapers it was observed that other crimes received more coverage than rape and this means that many rape cases go unreported. It is therefore, a case of "under-representation and not mis-representation".

On the Discussants' views on why there is low reportage of rape cases by the press, Dr. Onyinye's view from EBSU is presented thus:

The truth is that the press will only publish what they see or hear. If rape victims do not report such crimes to the press, how will it be 
published? So, the answer is that the victims do not draw the attention of journalists.

On this, Mrs. Onyido from ESUT disagreed thus:

No, No, No, I totally disagree with you. How will the victims report to the press when some of them do not even know their rights or even how and where to see journalists. Remember there is NAWOJ i.e. association of women journalists in every state. They are not doing their jobs, they should enlighten and sensitive women to stand up and fight for their right instead of dying in silence.

These views as reflected in the answers given by these discussants clearly show that low coverage of rape cases is caused by low reportage of rape cases by media houses and secondly due to low sensitization and enlightenment of women on such issues. This finding is in line with the Agenda setting theory of the press which emphasizes that the media tell their audiences what to think about. This shows that the amount of coverage or prominence given to rape cases or similar cases involving women or their rights will determine how knowledgeable women will be pertaining to such issues.

When asked whether they know about the provisions of the law of the Federation that states that any man that rapes a child will be imprisoned for life, they uniformly agreed they are aware of what the law says about rape and its consequences. But on whether they have heard or witnessed someone imprisoned or punished for committing rape, Dr. Onwuka, from ANSU said:

I have neither heard nor seen a man imprisoned for committing rape. The only thing you read on few newspapers are cases of rape. You do not even know whether those people are taken to the court. So most men who commit rape go unpunished and this is why many men do it every day. Once two or three men are jailed, others will be deterred from doing it because of the consequences.

This view reveals that although there are provisions in the law of the federation that stipulated various punishments for offenders, only few rape cases are tried. This is also in line with the reports of Guardian Newspaper (Friday 7, 2014, p. 20) which states that: some NGO's recorded 115 incidents and complaints on rape but only 12 cases taken up with the police while non of them was successfully prosecuted". This finding may also be the cause for non-reportage of rape cases to the police or to the media. Since most rape cases, even when reported or published, tend not to be prosecuted successfully, many women may feel it is a waste of time reporting such cases to either the media or the police. 
The Discussants' views on whether the dressing patterns of young girls contribute to the rising cases of rape, attracted total criticisms of modern dressing patterns of young girls and they agreed that it is one of the reasons why rape cases are increasing alarming. This finding is in line with Oduah $(2014$, p. 10) view that incident dressing constitutes another factor that sometimes make young girls victims of rape".

Finally, on how under-representation of rape cases could be stopped by the Nigerian press, the discussants suggested the following.

1. That NAWOJ members i.e. (Nigeria Association of Women Journalists) team up with NUJ (Nigerian Union of Journalists) to enlighten and sensitize women about their rights generally while stressing the provisions of the law regarding rape and other crimes against women.

2. That headlines always be cast in national newspapers calling on victims of rape to always report to police and media houses nearest to them;

3. That rape cases be prosecuted once reported as this will encourage rape victims to always report such crimes while serving as deterrant to others who have such tendency to commit rape.

4. That journalist always give a follow-up on any published rape case as readers will be interested to know how rape cases are resolved by the appropriate legal authorities.

\section{Conclusion}

This study explored elite women's view of representation of rape cases by Nigerian press. It sought to find out whether the manner of representation of rape cases by the press could be termed "Mis-representation" or "under-representation". Agendasetting theory of the press served as the theoretical framework for the study while focus Group Discussion method was adopted as the research method. Explanation Building Technique was used in the analyses and presentation of research findings.

The findings revealed that rape cases covered by the Nigerian press received how coverage and prominence and as such, it could best be described as "underrepresentation" and not "mis-representation". Secondly, the study found that this under-representation of rape cases is caused by low reportage of rape cases by rape victims to the police or media and also due to non-sensitization/enlightenment of women in the provisions of the law, and their rights. This study attributed low reportage of rape cases by rape victims to non or low prosecution of the reported rape cases which usually make offenders free of punishments.

Indecent dressing among young girls, as the study found, is one of the factors why rape cases are increasing alarmingly. Finally, the study found that underrepresentation of rape cases could be handled by NAWOJ and NUJ members rising up to their responsibility of enlightening, and sensitizing women on their rights and 
on various provisions of the laws regarding rape and by giving follow-up coverage on rape cases.

\section{Recommendations}

In view of the findings, the study recommends the following:

1. That journalists in Nigeria stop under-representation of rape cases and give it the prominence it deserves;

2. That NAWOJ and NUJ members be socially responsible by sensitizing and enlightening women on their rights and on the provisions of the law of the federation on rape and other related crimes;

3. That rape cases be handled by the police and other legal bodies while offenders are prosecuted and given the punishment the offence deserves;

4. That rape victims be encouraged by the media, non-governmental organizations and other governmental agencies to always report cases of rape to appropriate authorities.

\section{References}

Asemah, E. (2011). Selected mass media themes. Jos: Jos University Press.

Baran, S.J. \& Davis, J. (2003). Assessing the quality in qualitative research. European Journal of communication. (3) 21-38

Eboh, S. (2011). Print Media coverage of rape cases: A study of selected Nigerian Newspapers. A Research work submitted to the Dept. of Mass communication Federal Polytechnic Oko.

Musbau, R. (2013). Between justice system \& rape epidemic. The Guardian, Sunday November 3, 2013 p. 53.

Nwammuo, A. N. (2013). Social media and perpetuation of violence against women in Nigeria: The case of facing death in Facebook. AFRREV LALIGENS. Vol. 2 (2) 1-10. Ethiopia.

Nwankwo, J. (2011). Understanding gender. Lagos: Zoom lens Publishers.

Naish, C. (2013). Rape and law. Lagos: Image Publishers.

Oduah, F. (2014a). Protecting child against rape and defilement: The role of the media. A paper presented at the 2014 Africa council for communication Education (ACCE) conference held on March, 2014 at University of Nigeria, Nsukka. 
Oduah, F. (2014b). Exploring media framing and representation of Rape cases in Nigeria: A study of selected Newspapers. M.Sc. thesis submitted to school of Postgraduate studies, Anambra State University.

Okonkwo, C. \& Naish, C. (2013). Criminal law in Nigeria. Ibadan: Spectrum Publishers.

\section{Cited Statuses}

Criminal Code Act 77, Laws of Federation 1990 section 357.

Criminal Code Law, CAP 36, Laws of Anambra State, Section 308

Penal Code, Section 282

Child's Right Act, 2003, Section 3.

\section{Cited Newspapers}

Saturday Sun of March 15, 2014

Sunday Sun of August 31, 2014

Sunday Sun of January 19, 2014

Daily Sun of October 31, 2013

Daily Sun of December 19, 2013

Guardian of June 6, 2013

Guardian of November 3, 2013

Vanguard of October 25, 2013 


\section{APPENDICES}

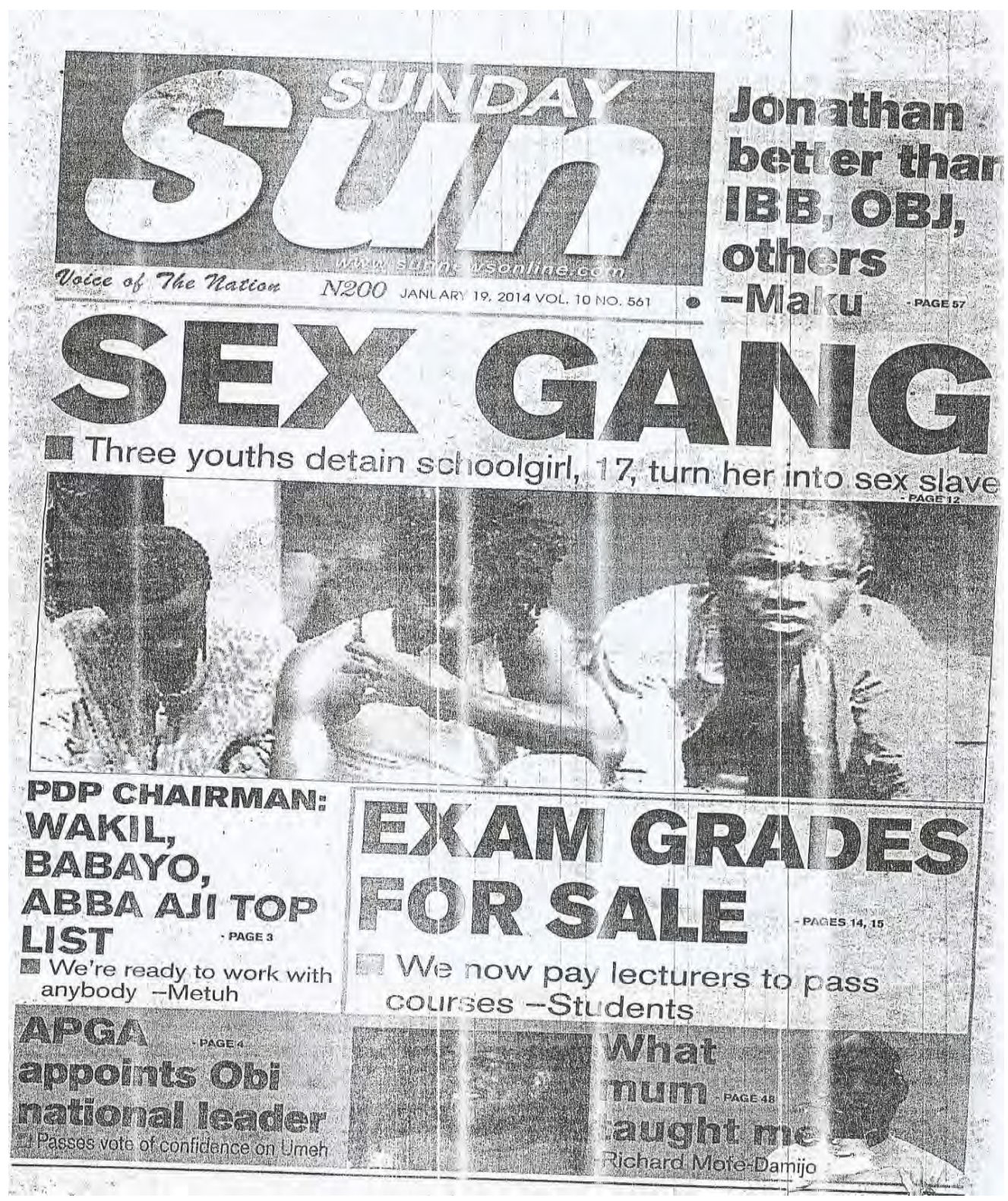

Copyright C IAARR 2014: www.afrrevio.net/laligens Indexed and Listed by AJOL \& EBSCOhost 


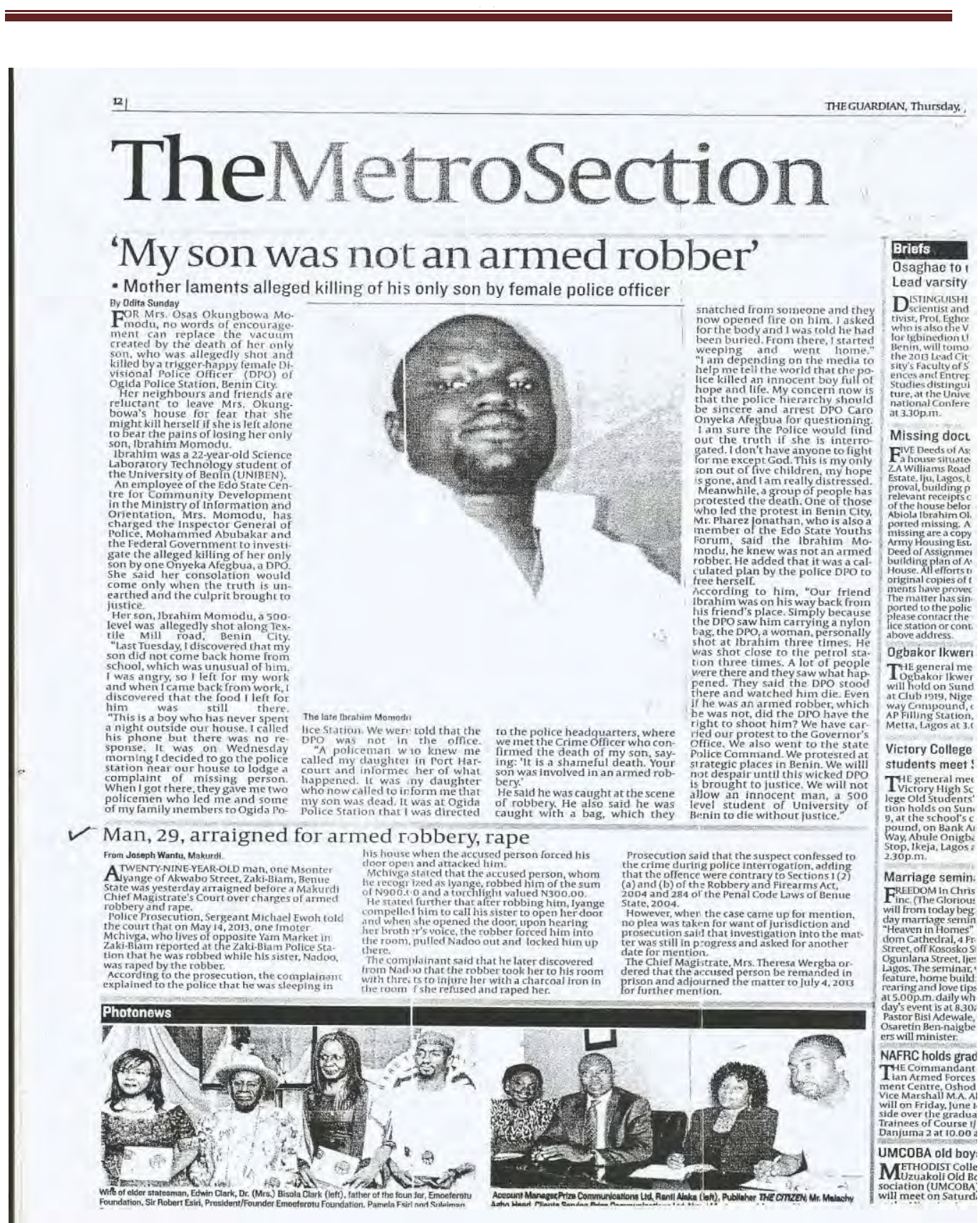




\section{i) TheMetroSection}

\section{$\checkmark$ Beware! Rapists on the prowl...}

- Police parade seven rapists in Ekiti, victims narrate their ordeals

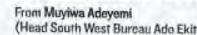

$\mathrm{E}_{\text {raised }}^{\text {KmItate Police Com }}$

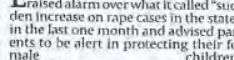

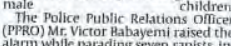

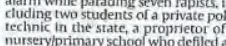

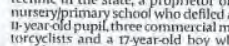
raped at thitreyearold boy

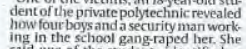

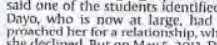

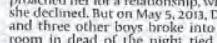

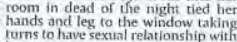
in
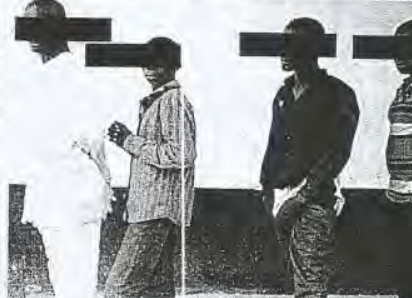

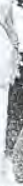

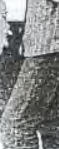

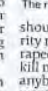

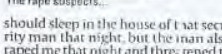

缩

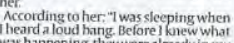
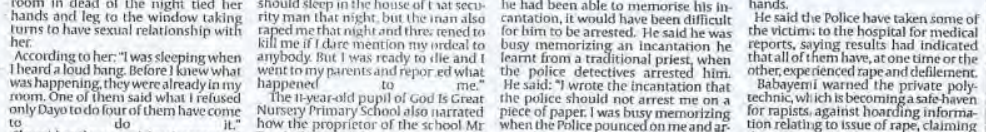

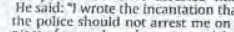

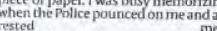
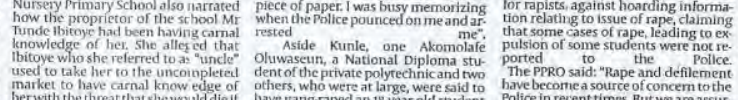

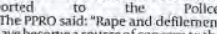
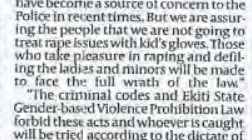

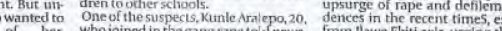

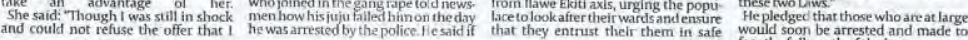
Yoruba-speaking American, Kayode Oyinbo, takes Lagos Assembly by storm

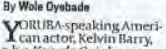

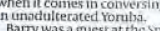

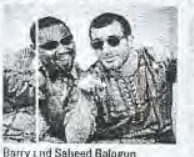

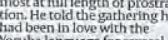
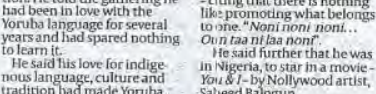

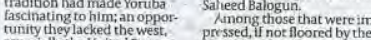

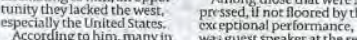

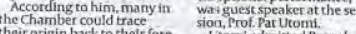

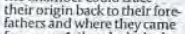

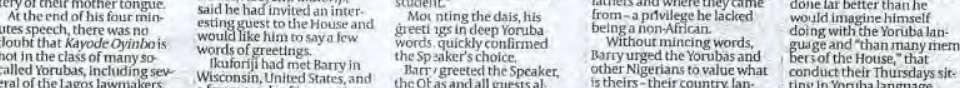

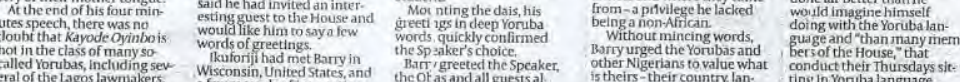
troniadidmitred barry
done lar better than he

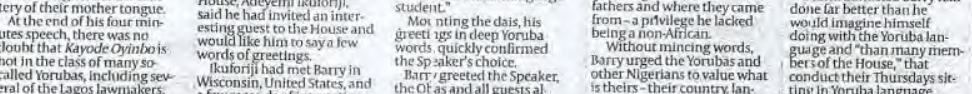

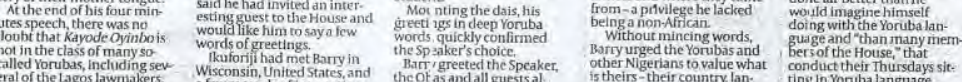

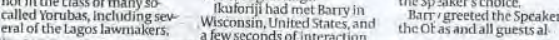
82-year-old in Edo

Police arrest
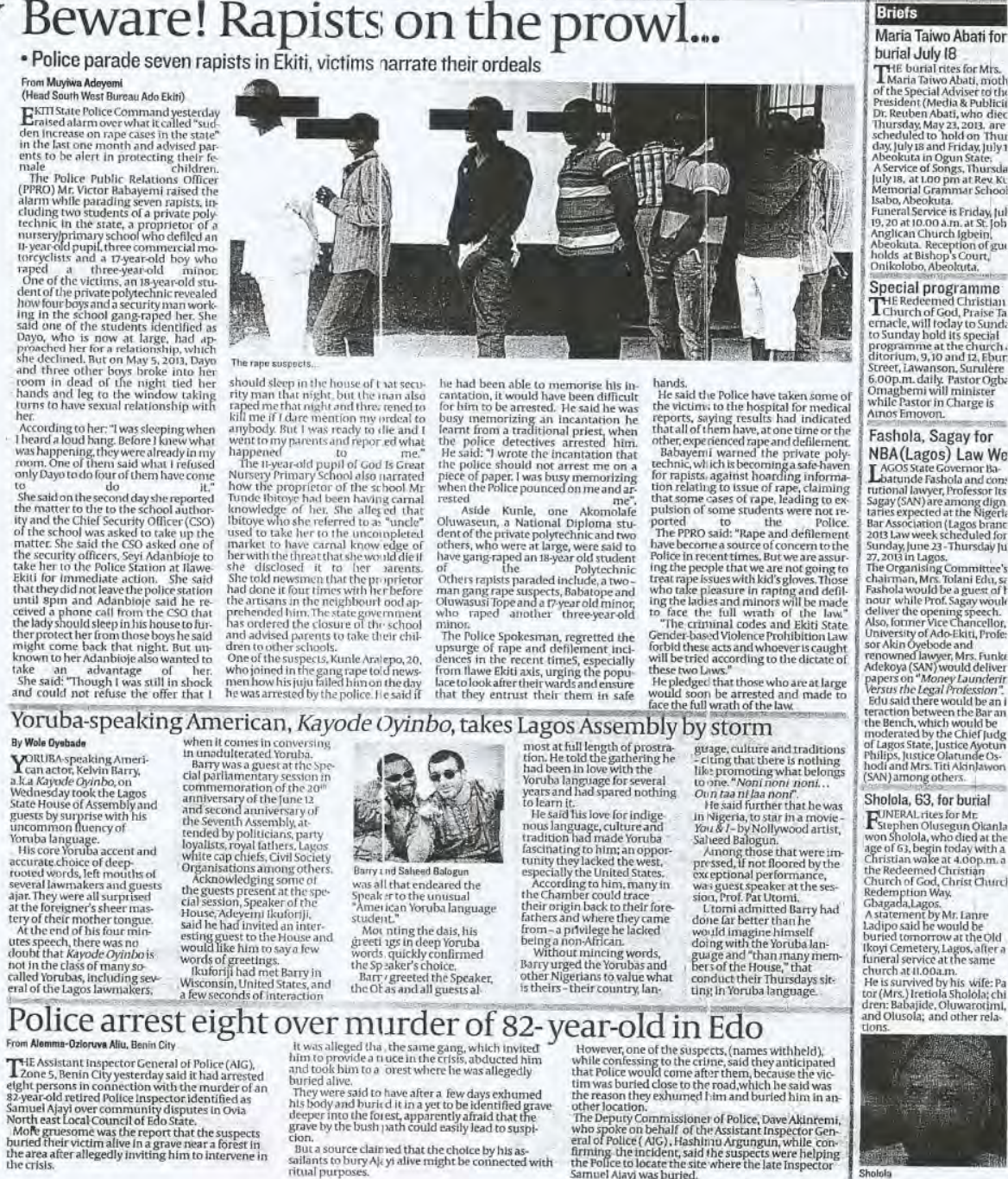

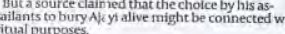

Sholisat 
The Views of Women of Press Coverage of Rape Cases in Nigeria: A Misrepresentation or an Under-representation?

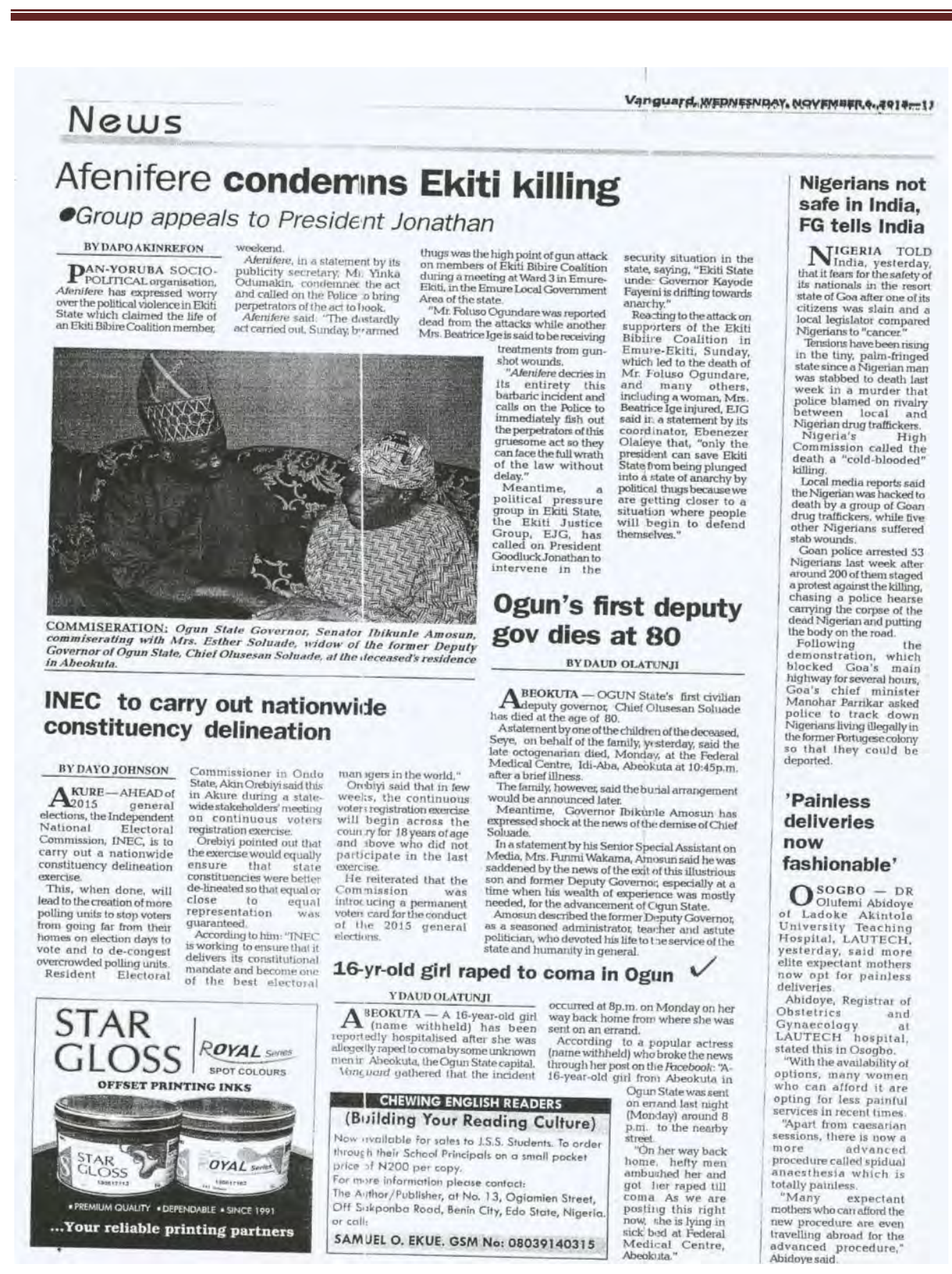

Copyright (C) IAARR 2014: www.afrrevjo.net/laligens 
G-Vanguara, WEDNESDAY, DECEMBER 11, 2013

News

Trader arraigned over alleged car theft

BYONOZUREDANTA

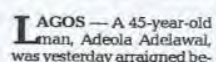
was yesterday arraignedbe-
fore a Lagos Magistrate
Court in stealing of a fairly used car stealingorth The defendant who resides
at 12 , Shomade Street in Ikoroduarea of Lagos, is facstealing preferred against him by the police The defendant who is a Magistrate AO. Akinde. The prosecutor, Sergeant
Chinalu Uwadione, told th Chinalu Uwadione, told the
court that the defendant com mitted the alleged offence on
May 22, 2013 at about 10. am May 22, 2013 at about 10.an stole a fairly used Honda Ancord car with number plate J30A41144465 and chassis IHGCM66503A094209 b longing to one Ala According to the prosect tor, the offence is contrary section 278 and punishab criminal laws of Lagos state of Nigeria, 2011. Earlier, the defendant
pleaded not guilty to the pleaded not guilty to
charge against him.

\section{1}

\section{Chief, 2 others arrested for robbery}

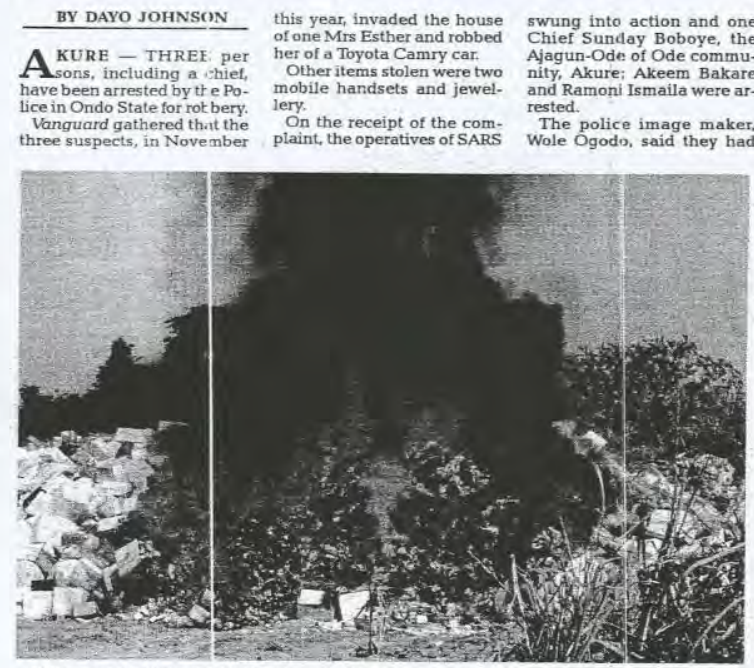

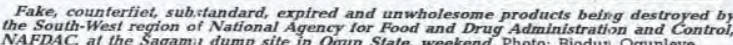

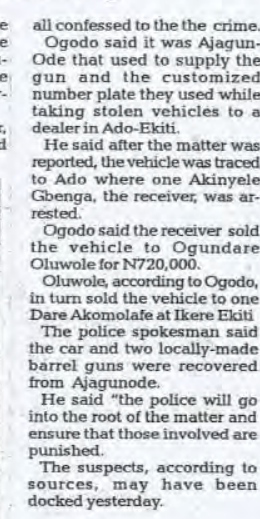
sources, may according to

\section{Alleged \\ cultist \\ remanded over murder}

\section{9 docked for stealing dogs in Katsina}

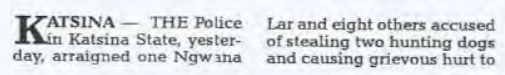

\section{Two security men remanded in prison over robbery, rape}
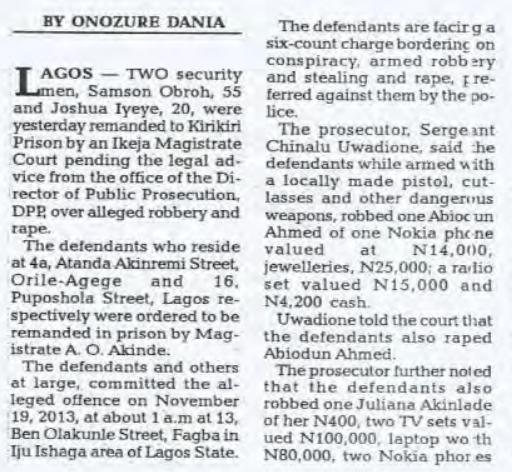

valued N100,000 and a wed-
ding ring worth NB00,000 According to the prosecutor the defendants raped one He said the offences are of Armed Robbery and Firearms (Special Provisions) Act,
Cap. 398 Vol. XXii, laws of the Federation of Nigeria 1990 as amended. The offence is also punishthe criminal laws of Lagos State of Nigeria 2011.
Earlier, the defendants ha Earlier, the defendants had
pleaded not guilty to the charges against them.
Their plea was not taken the magistrate ordered tha they be remand
the DPP's advice She, however, adjourned the
case to January 23,2014 .
BY ONOZURE
DANIA

I Agos - JUSTICE LKudirat Jose of a La.
gos High Court sitting in manded a suspected
cultist, Rasheed Bello, in Cultist, Rasheed Bello, in
Kirikiri prison over alleged murder of one Busurat Ogunlaja and
for also being a member of secret society. The defendant is lacing
a two-count- charge a two-count- charge
boarding on conspiracy and murder. The prosecution coun-
sel, Kester, told the court sel. Kester, told the court
that Rasheed and others at large committed the alleged crime on February 3,2011 . and his accomplices who are members of Aye Confratanity murdered
the deceased at 8 . Odofin Street, in Epe area of Lagos. not guilty to the charges was not taken as the judge ordered that he be However,

the matter asked Justice Jose for a trial date. She adjourned the cas Ikeja, yesterday, re- 


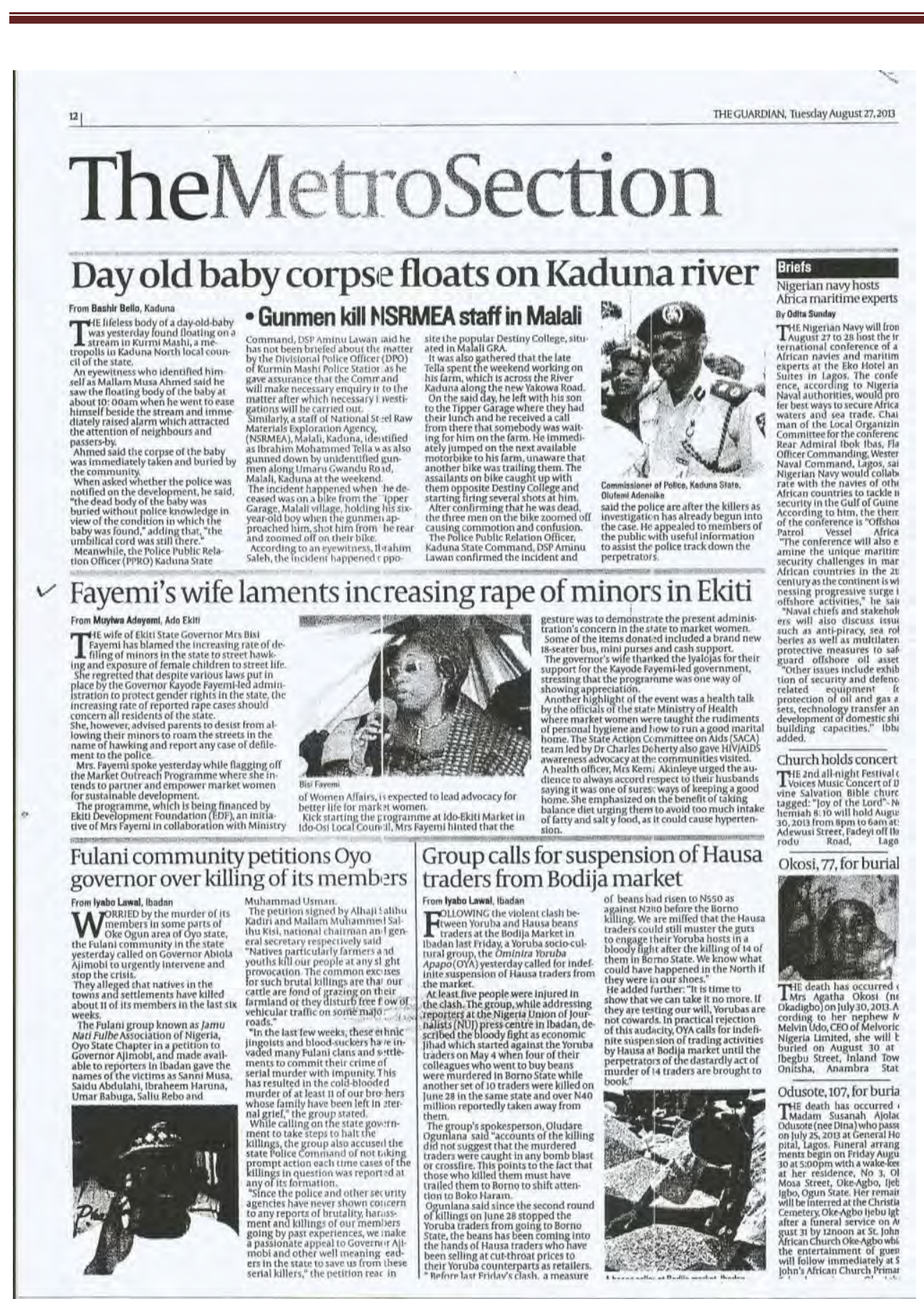

Copyright C IAARR 2014: www.afrrevjo.net/laligens 


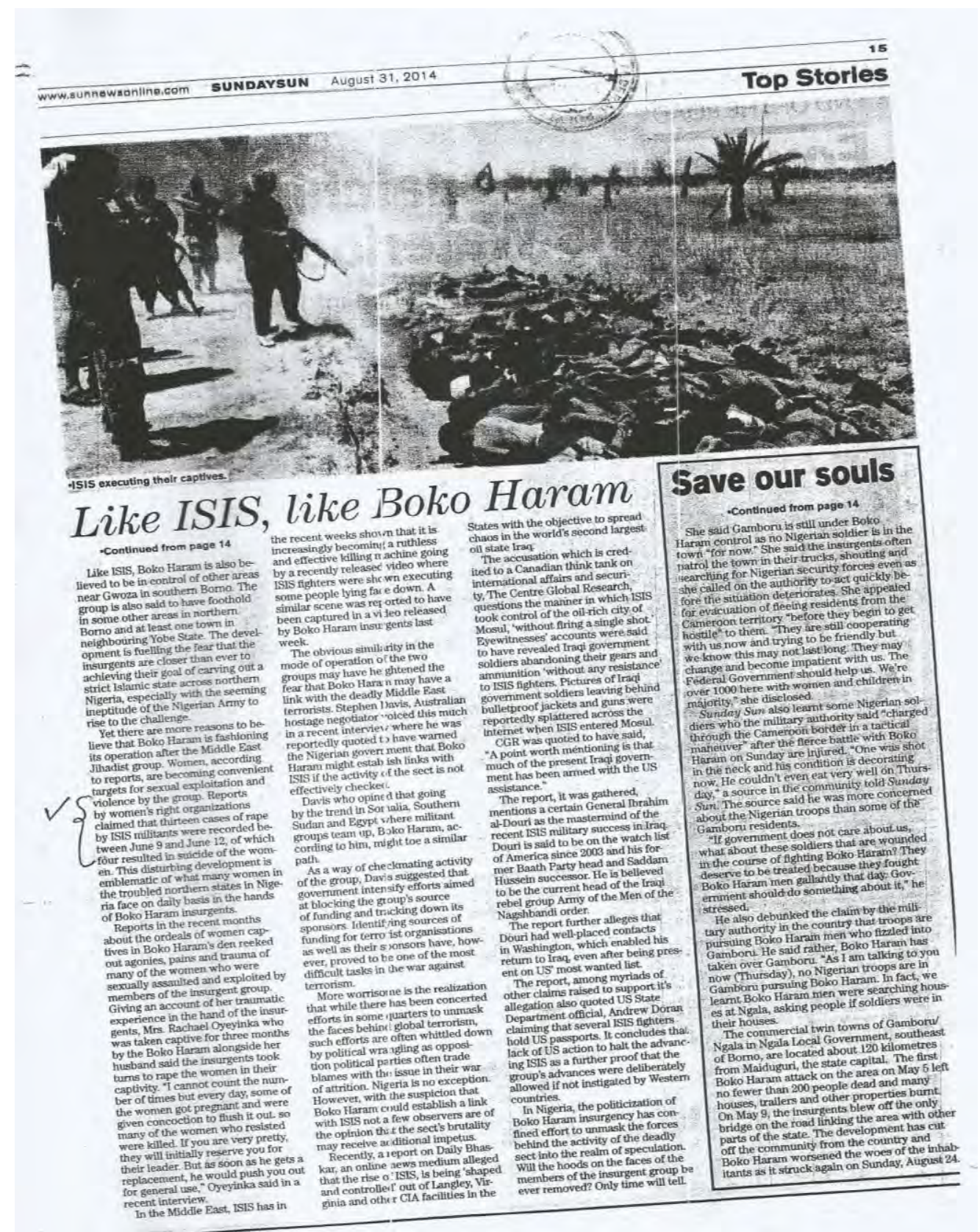

Copyright (C) IAARR 2014: www.afrrevjo.net/laligens 
The Views of Women of Press Coverage of Rape Cases in Nigeria: A Misrepresentation or an Under-representation?

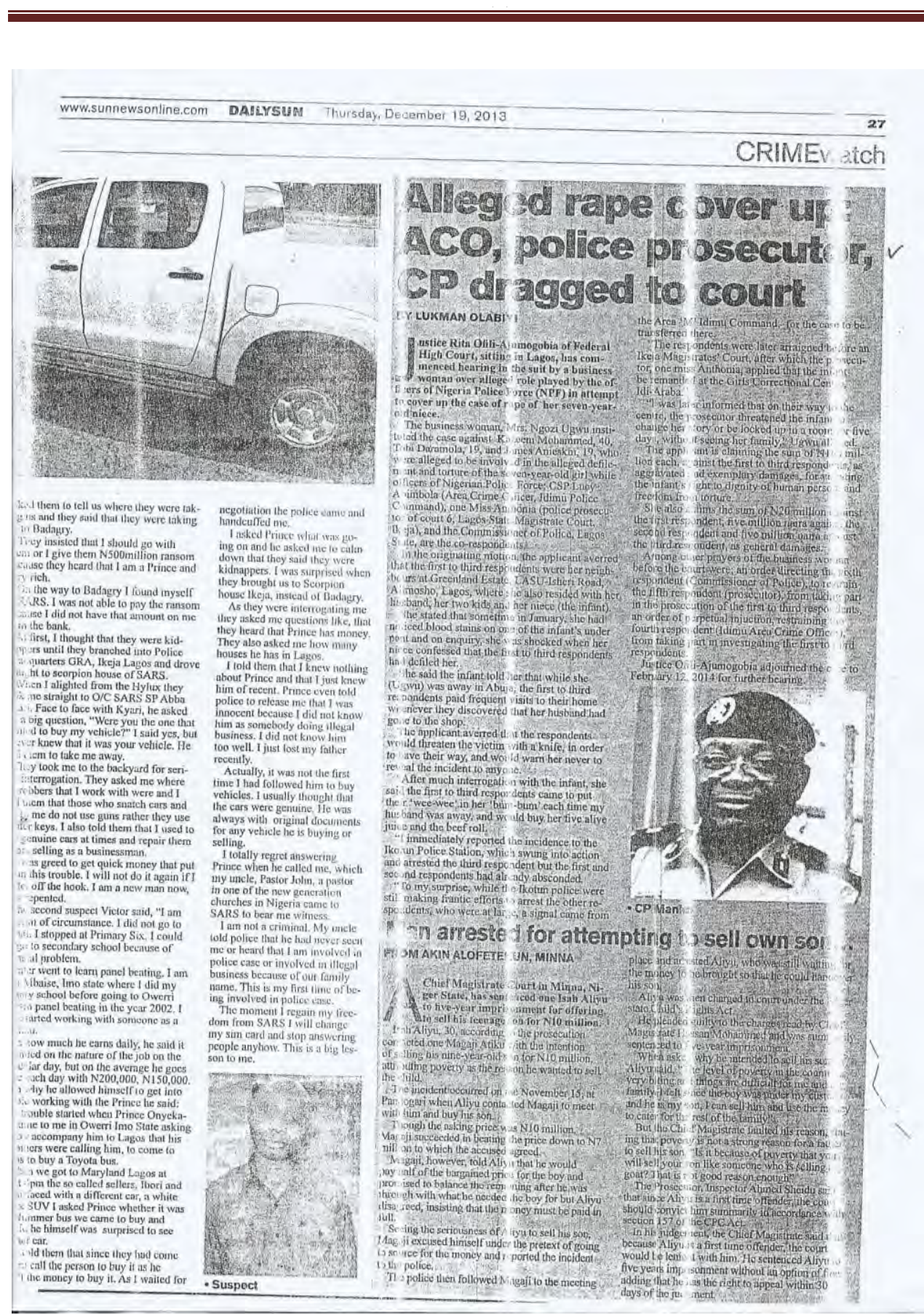

Copyright (C) IAARR 2014: www.afrrevjo.net/laligens 


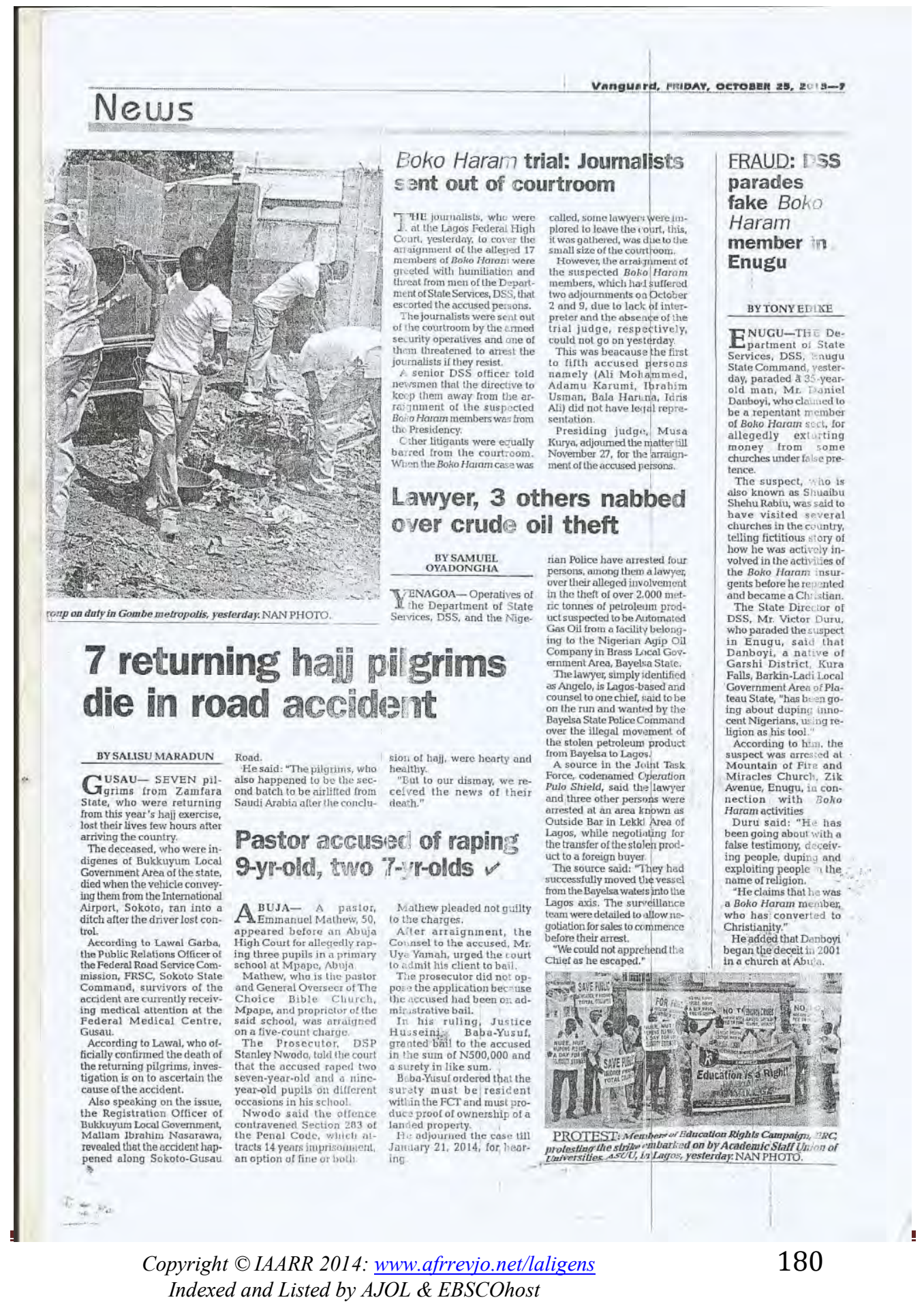




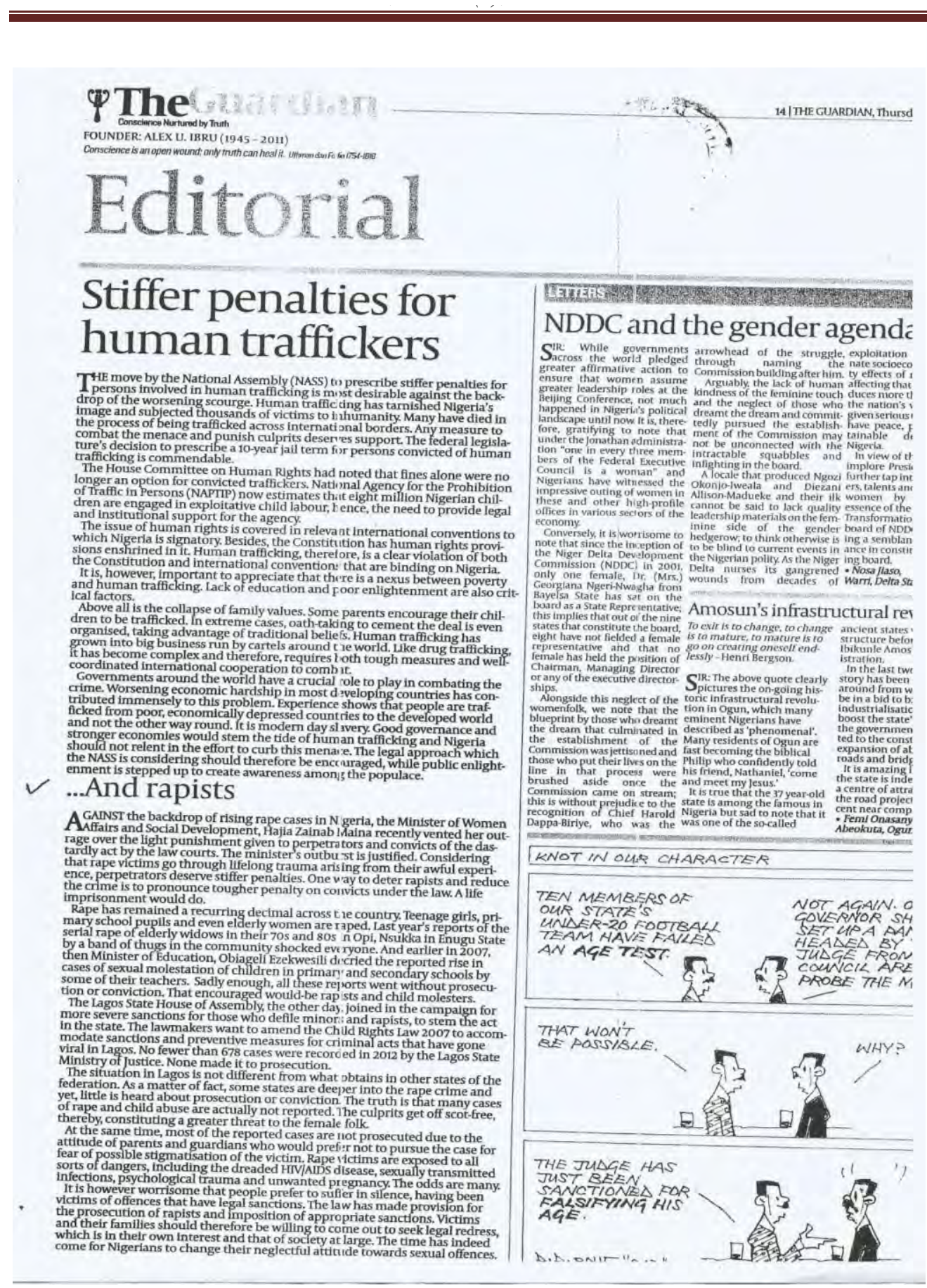

Copyright (C) IAARR 2014: www.afrrevjo.net/laligens Indexed and Listed by AJOL \& EBSCOhost 


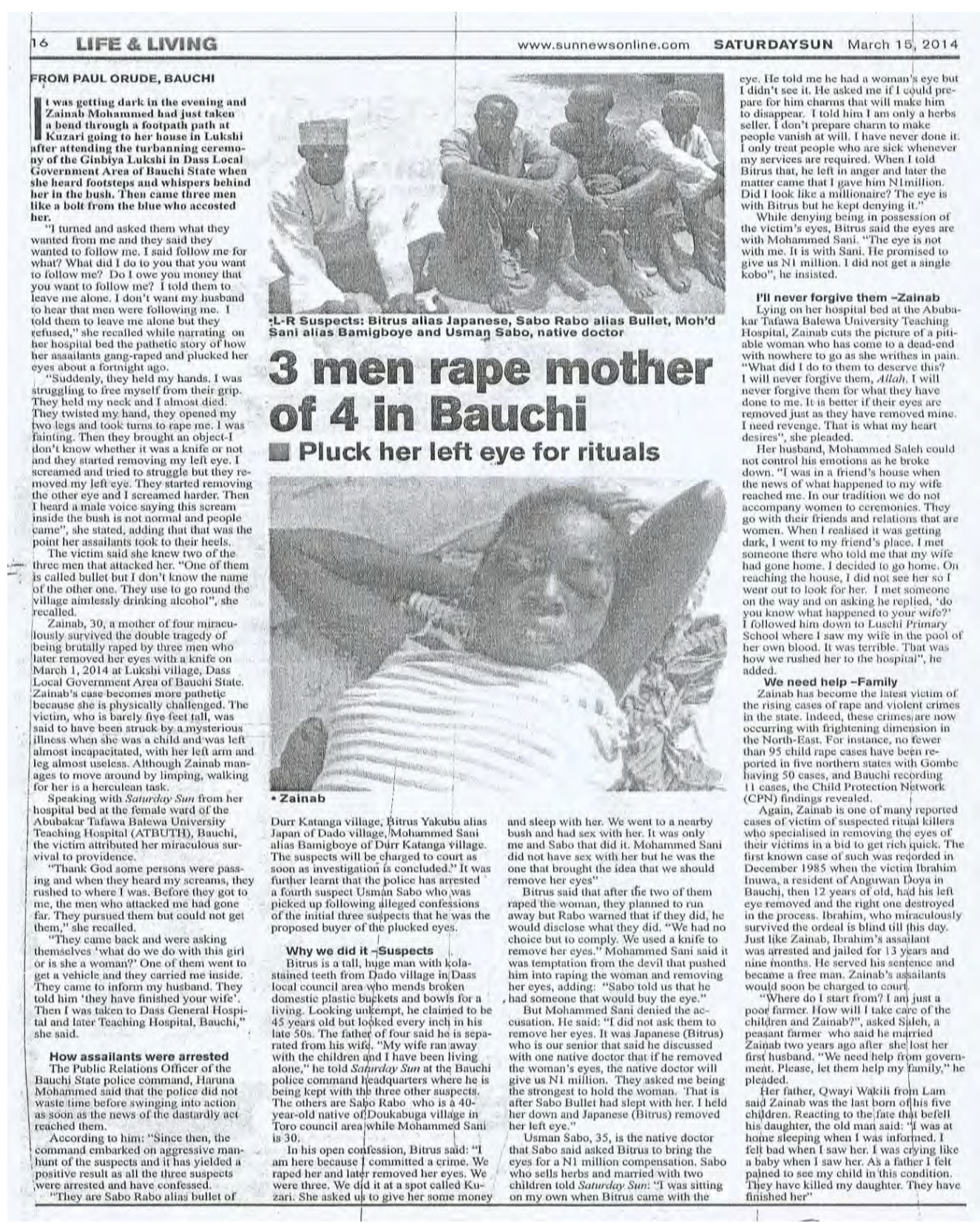

